hours.

\section{BUTTERFLIES ATTRACTED TO LIGHT AT ARALAM WILDLIFE SANCTUARY, KERALA}

\author{
Vinayan P. Nair \\ 3/IV College Quarters, P.O. Madappally College, Vatakara, \\ Kozhikode District, Kerala 673102, India.
}

A large number of insects are attracted to light. Moths and sometimes butterflies are highly attracted to light. Although analyses of moth catches at light are occassionally published, nocturnal record of butterflies are few. Some butterflies are however known to be crepuscular fliers.

Usman (1956) In his paper "Some insects attracted to light" recorded Red Pierrot, Talicada nyseus, attracted to light at Bangalore. Shull and Nadkerny (1967) have reported five species of the family Satyridae and a Lycaenid from Surat Dangs, Gujarat. Sharma and Chaturvedi (1999) recorded Black Rajah, Charaxes fablus, attracted to light in Tadoba National Park. The present paper reports butterfly attraction to light at Aralam Wildlife Sanctuary, Kerala.

Aralam Wildlife Sanctuary is located along the western slopes of the southernWestern Ghats and is the northern most wildlife sanctuary of Kerala, situated southeast of Kannur District $\left(11^{\circ} 49^{\prime}-11^{0} 50^{\prime} \mathrm{E} \& 7^{\circ} 49^{\prime}-75^{0} 57^{\prime} \mathrm{N}\right)$. During my stay at Aralam Sanctuary in February-April 2001, for a study on some aspects of the behavioural ecology of butterflies, the following observations were recorded. While observing the insects attracted to the CFL light on the verandah of the staff quarters and the tubelight at the inspection Bungalow at Valayamchal (100m.), I witnessed these baffling incidents on February 23, February 28 and on April 1, 2001.

On February 23 at about $2030 \mathrm{hr}$ I saw a lycaenid attracted to and at times dashing and then resting near the CFL light at the verandah of the staff quarters. Its movement and orientation were quite similar to that in the field in the morning. The butterfly was later identified as Gramblue, Euchrysops cnejus (Fabricius) (Lycaenids: Polyommarinae). During the night of February 28, I witnessed the second incident. At around $2000 \mathrm{hr}$, I saw a small Grassblue butterfly flying around and then resting and again flying around the CFL light at the verandah of the Staff quarters. Later the butterfly was even identified as Tiny Grassblue, Zizula hylax (Fabricius). Both lycaenids were seen mud puddling on the river banks in front of the staff quarters during morning
On April 1 at around 2100hr, I witnessed the last incident. A Satyrid was seen attracted to the tubelight in the centre hall of the Inspection Bungalow at Valayamchal. As usual with a slow jerky flight, it came towards the light and rested in a shadow under a table. It flew in the usual Satyrid manner not close to the tube light but close to the floor and then rested in the shadow. The movement and orientation was quite similar to that seen during day time in the field. No dashing at the light was seen here as in the case of other butterflies attracted to light. Later it was identified as the Nigger, Orsotrioena medus (Fabricius) (Nymphalidae: Satyrinae).

These records in comparison with previous records throw some doubt on the popular idea that butterfly activity is exclusively diurnal. Moreover the orientation and movement of these butterflies showed at light in the present observation was identical to that shown by them during diurnal hours. Further studies will help in interpreting this interesting phenomenon. I appeal to researchers and butterfly observers to publish their observations on butterfly attraction to light and their behaviour at light, rather than treating such incidents and captures as anomalies.

\section{Acknowledgement}

I thank A. Padmanabhan, Wildlife Warden, Aralam Wildlife Sanctuary, for research permission and T.V. Govindan Nambiar (Forester) and family for their hospitality and help. I also thank Dr. C. Radhakrishnan (Joint-Director, ZSI, WGRS, Kozhikode) \& Dr. P.M. Sureshan (ZSI, Kozhikode) for constant encouragement and facilities. Encouragement and help rendered by Md. Jafer Palot (ZSI, Kozhikode) in identifying the Blues is also sincerely acknowledged.

\section{References}

Sharma, R.M. and N. Chaturvedi (1999). Black Rajah, Charaxes fabius attracted to light in Tadoba National Park. Journal of the Bombay Natural History Society 96(1): 168-169.

Shull, E.M. and N.T. Nadkeray (1967). Insects attracted to mercury vapour lamp in the Surat Dangs, Gujarat State. Journal of the Bombay Natural History Society 64: 256-266.

Usman, S. (1956). Some insects attracted to light. Part III. Journal of the Bombay Natural History Society 53(3): 482-484. 